\title{
In-toto removal of a subretinal Cysticercus cellulosae by pars plana vitrectomy
}

\author{
Michiel H A Luger, Jan S Stilma, Peter J Ringens, Joop van Baarlen
}

\begin{abstract}
A case of subretinal cysticercosis was treated with laser coagulations round the cyst prior to surgery. In-toto removal of the living cysticercus was performed by pars plana vitrectomy. Two weeks after surgery 25/20 vision was regained. Histopathology of the cyst confirmed the clinical diagnosis.
\end{abstract}

Ocular cysticercosis occurs rarely, but the diagnosis is very important. In most cases untreated intraocular cysticercosis will eventually lead to blindness. ${ }^{12}$

The cysticercus is generally found subretinally, but any area of the eye or ocular adnexa may be affected. ${ }^{1-4}$ It enters the posterior segment of the eye through the posterior ciliary arteries, reaching the subretinal space. From there the parasite may migrate into the vitreous cavity.

\section{Case report}

A 44-year-old male visited our clinic in January 1990 with a red, irritated left eye and complaints of blurred vision for two months. He had travelled to Indonesia in the summer of 1989.

The visual acuity of the right eye was $25 / 20$. It was entirely normal. On the left the visual acuity was $20 / 30$, motility was normal, and the intraocular pressure was $14 \mathrm{~mm} \mathrm{Hg}$. Slit-lamp examination showed a mild conjunctival injection; the anterior chamber had $2+$ cells and flare, and the

F C Donders Institute of Ophthalmology, Utrecht University Hospital, The Netherlands M H A Luger J S Stilma

P J Ringens

Department of Pathology, Utrecht University Hospital J van Baarlen

Correspondence to: M H A Luger, MD, F C Donders Institute of Ophthalmology, Utrech University Hospital, PO Box 85500,3508 GA Utrecht, The Netherlands.

Accepted for publication 21 February 1991

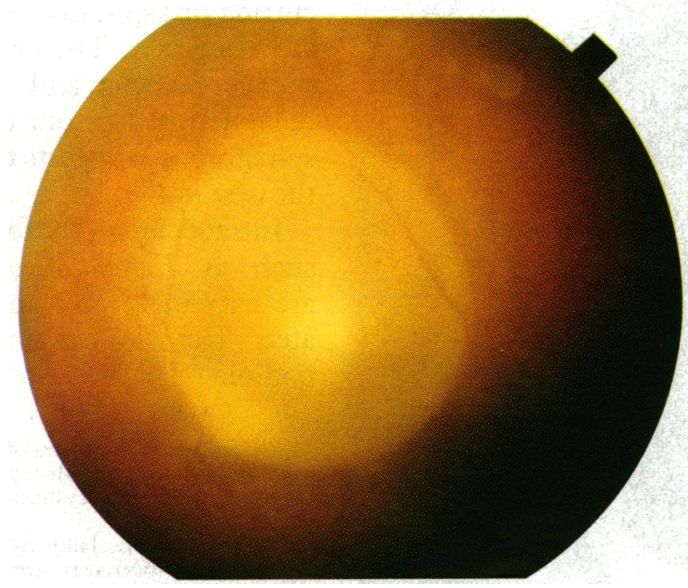

Figure 1 Fundus photograph showing the subretinal cysticercus. The laser coagulations surrounding the cyst are vaguely discernible.

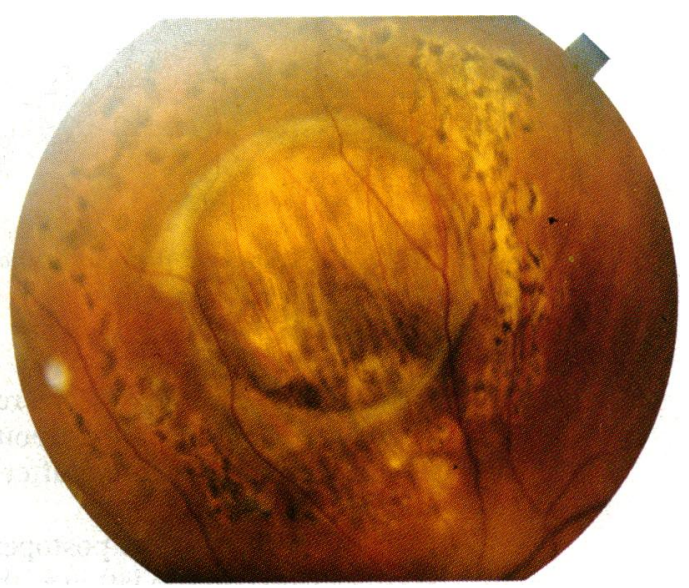

Figure 2 Fundus photograph two months postoperatively. The optic media are clear and the retina is fully attached.

vitreous cavity had $1+$ cells. Funduscopy disclosed a subretinal, translucent cyst, 4 disc diameters in size in the superonasal quadrant. A central dense white spot, mobile under bright illumination, indicated the location of the larva inside the cyst (Fig 1). The optic nerve head, macula, and retinal vessels showed no abnormalities.

Preoperative standardised A-scan ultrasonography revealed two medium to high amplitude echos, indicating a space between the inner cyst wall and the overlying retina. The B-scan showed a subretinal bladderworm with two hooklets.

A general physical and neurological examination gave normal results. The white blood count was normal except for 5\% eosinophils. Enzyme linked immunosorbent assay (ELISA) gave positive results for Taenia solium/Cysticercus cellulosae immunoglobulins $(1: 80)$. Stool specimens, a skull $x$-ray, CT brain scan, and cerebrospinal fluid were normal. There was no evidence of generalised cysticercosis.

Two weeks prior to surgery the subretinal cyst was sealed by surrounding argon laser photocoagulations (wavelength $577 \mathrm{~nm}$, spot size $250 \mu \mathrm{m}, 200 \mathrm{~ms}, 0.2-0.35 \mathrm{~W}$ ) (Figs 1 and 2). Systemic prednisone was administered one day preoperatively until one day postoperatively.

An initial attempt to remove the cysticercus by sclerotomy was abandoned because of the location of the cyst underneath a vortex vein. A pars plana vitrectomy was therefore performed. Endodiathermy of the raised retina overlying the 


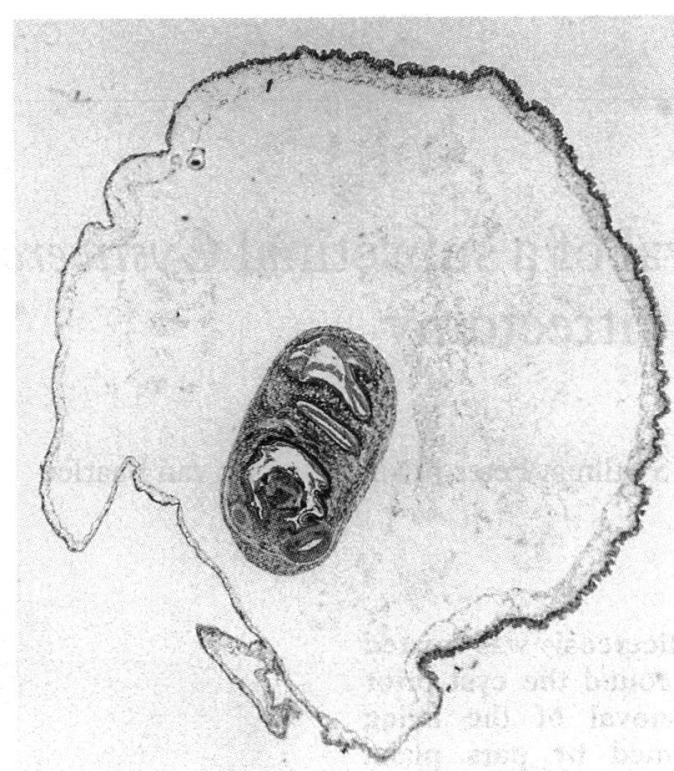

Figure 3 Histological section of the cyst. (Haematoxylineosin, $\times 30$.)

cyst allowed a safe retinotomy. The cyst was pulled into the vitreous and extracted from the eye in one piece after enlargement of the pars plana incision.

Two weeks postoperatively visual acuity was $25 / 20$ in the left eye, the optic media were clear, the retina was fully attached, and the intraocular inflammation had subsided (Fig 2).

Macroscopic and histological examination confirmed the diagnosis. Within a $3 \mathrm{~mm}$ cyst a Cysticercus cellulosae larva was found, with several hooks and suckers, conforming to the characteristics of the Taenia solium scolex (Figs 3, 4).

\section{Discussion}

Cysticercus cellulosae is the larval stage of Taenia solium, the swine tapeworm. Human cysticerco-

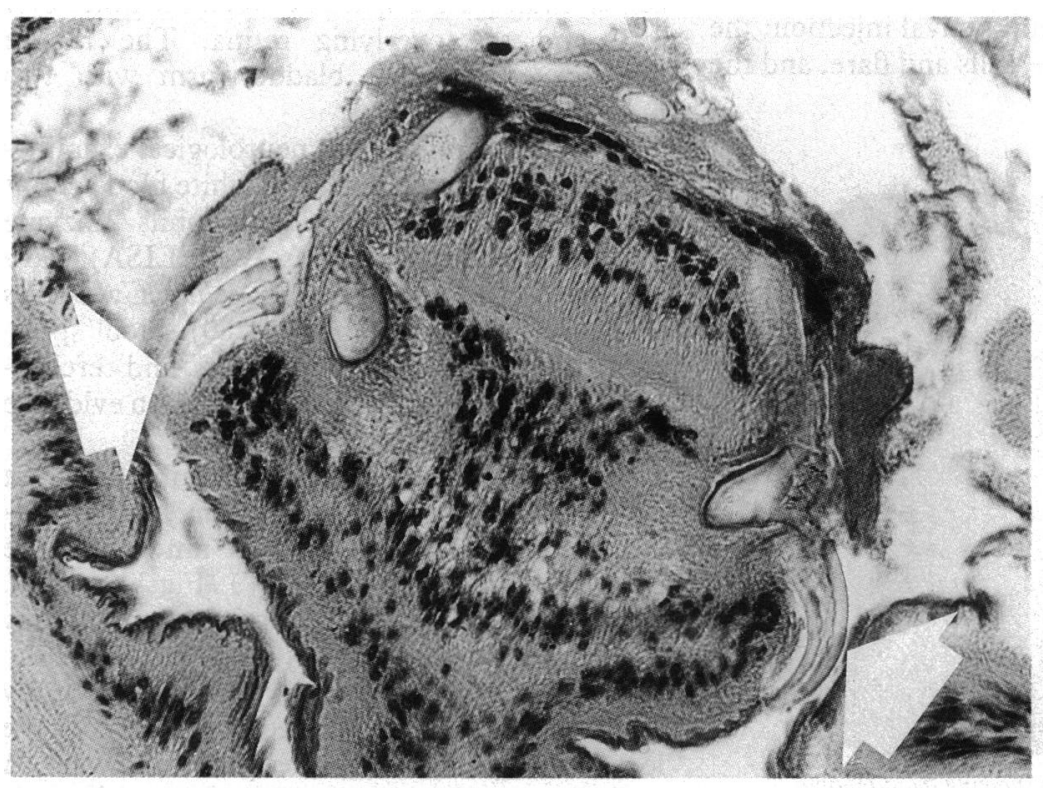

Figure 4 Histological section of the scolex within the cyst. Note the two characteristic hooks (arrows). (Haematoxylin-eosin, $\times 420$.) sis can be acquired when man ingests the eggs of $T$. solium. An intraocular living cysticercus will initiate a foreign body reaction, varying from a mild uveitis to a panophthalmitis. When the parasite is left untreated it will eventually die after two to four years. The accompanying release of toxins induces an inflammatory reaction that may lead to destruction of the eye, though there are exceptions. ${ }^{125}$ Early removal of the cyst is crucial.

The management of subretinal cysticercosis has taken various forms. Antihelminthic drugs, such as praziquantel, are ineffective for intraocular cysticercosis. ${ }^{67}$

Xenon and argon laser photocoagulation have been reported to be an efficaceous treatment of small subretinal cysticerci (less than $8 \mathrm{~mm}$ ). ${ }^{89}$ Coagulation has the undesired side effect that the dead larva is left inside the eye. ${ }^{10}$ Systemic and topical steroids have been reported to suppress the subsequent inflammatory reaction. ${ }^{1211}$

The most effective method of preserving function in an eye with intraocular cysticercosis is surgical removal of the larva. Subretinal parasites can be removed through a sclerotomy. ${ }^{11-18}$ But this technique carries some risks. Extensive periocular surgery may be required to gain adequate exposure. ${ }^{121219}$ Inadequate localisation may lead to non-removal of the parasite. Peroperative migration of the cyst within the subretinal space and migration into the vitreous have been described. ${ }^{1-3}{ }^{13} 14$ Other possible complications are retinal detachment, retinal tear with vitreous loss, vitreous haemorrhage, and bacterial endophthalmitis.

Vitrectomy has been used to remove intravitreal cysticerci. ${ }^{311}$ 13-15 20-22 Steinmetz et al reported the successful removal of a subretinal cysticercus after fragmentation of the cyst inside the vitreous cavity, using pars plana vitrectomy. ${ }^{23}$ This method has several advantages over a classic sclerotomy. The visibility of the parasite during surgery is excellent and the risk of subtotal cyst removal and choroidal bleeding, as in the external approach, is avoided. The risks of a retinotomy can be minimised by preoperative application of delimiting laser photocoagulations (Fig 2). This also prevents peroperative cyst migration within the subretinal space. $^{8}$

The risk of spilling cyst contents is minimal if cutting or aspiration of the cyst can be avoided, as in our case. The presence of a space between the cysticercus and the overlying retina, as demonstrated by our preoperative A-scan ultrasonography, suggests the possibility of removing the cyst in toto.

Intraocular cysts formed by other parasites, such as Echinococcus and Taenia sagginata, are extremely rare and can only be differentiated from Cysticercus cellulosae by histopathology. ${ }^{1}{ }^{24}$

1 Duke-Elder S. Diseases of the uveal tract. System of ophthalmology. St Louis: Mosby, 1966; : 478-88.

2 Junior L. Ocular cysticercosis. Am $\mathcal{f}$ Ophthalmol 1949; 32: 523-48.

3 Kruger-Leite E, Jalkh AE, Quiroz H, Schepens CL. Intraocular cysticercosis. Am f Ophthalmol 1985; 99: 252-7.

4 Malik SRK, Gupta AK, Choudry S. Ocular cysticercosis. Am f Ophthalmol 1968; 66: 1168-71.

5 Weve HJM. Ein Fall von doppelseitigem Cysticercus intraocularis. Spontanheilung am rechten Auge. Heilung durch 
Galvanokauterisation am linken Auge. Klin Monatsbl Augenheilkd 1931; 87: 597-602.

6 Santos R, Chavarria M, Aguierre AE. Failure of medical treatment in two cases of intraocular cysticercosis. $A m \mathcal{F}$ Ophthalmol 1984; 97: 249-50.

7 Kestelyn P, Taelman $\mathbf{H}$. Effect of praziquantel on intraocular cysticercosis. Br f Ophthalmol 1985; 69: 788-90.

8 Santos R, Dalma A, Ortiz E, Sanchez-Bulnes L. Management of subretinal and vitreous cysticercosis: role of photo-

9 Huismans H. Subretinale Zystizerkose. Klin Monatsbl Augenheilkd 1987; 191: 142-5.

10 Esteban M. Subretinal cysticercus. Am f Ophthalmology 1947; 30: 76.

11 Arciniegas A, Gutierrez F. Our experience in the removal of intravitreal and subretinal cysticerci. Ann Ophthalmol 1988 20: 75-8.

12 Bartholomew RS. Subretinal cysticercosis. Am $\mathcal{f}$ Ophthalmol 1975; 79: 670-3.

13 Aracena T, Perez-Roca F. Macular and peripheral subretinal cysticercosis. Ann Ophthalmol 1981; 13: 1265-7.

14 Franken S. Intraocular cysticercus. Ophthalmologica 1975; 171: 7-10.

15 Topilow HW, Yimoyines DJ, Freeman HM, Moo Young GA,
Addisson R. Bilateral multifocal intraocular cysticercosis Ophthalmology 1981; 88: 1166-72.

16 Dunlap EA. Surgical extraction of intra-ocular cysticercus. .

17 Reddy PS, Satyendran OM. Ocular cysticercosis. Am $\mathcal{F}$

Ophthalmol 1964; 57: 664-6.
18 Balakrishnan E. Bilateral intraocular cysticerci. $\mathrm{Br} f$ Ophthalmol 1961; 45: 150-1.

19 Segal P, Mrzyglod S, Smolarz-Dudarewicz J. Subretinal cysticercosis in the macular region. Am $\mathcal{F}$ Ophthalmol 1964; 57: 655-64.

20 Hutton WL, Vaiser A, Snyder WB. Pars plana vitrectomy for removal of intra-vitreous cysticercus. Am $\mathcal{f}$ Ophthalmol 1976; 81: 571-3.

21 Messner KH, Kammerer WS. Intraocular cysticercosis. Arch Ophthalmol 1979; 97: 1103-5.

22 Zinn KM, Guillory SL, Friedman AH. Removal of intravitreous cysticerci from the surface of the optic nervehead. Arch Ophthalmol 1980; 98: 714-6.

23 Steinmetz RL, Masket S, Sidikaro Y. The successful removal of a subretinal cysticercus by pars plana vitrectomy. Retina 1989; 9: 276-80.

24 Manschot WA. Intraocular cysticercosis. Arch Ophthalmol 1968; 80: $772-4$. 